\title{
Nux Vomica Seed
}

National Cancer Institute

\section{Source}

National Cancer Institute. Nux Vomica Seed. NCI Thesaurus. Code C87566.

An herbal remedy derived from the seeds of the everg reen tree Strychnos nux-vomica, a native to southeast Asia and northern Australia. The seeds, found inside the green to orange-colored fruit, contain the alkaloids strychnine and brucine that can act as a CNS stimulant at therapeutic doses. 